\title{
Derleme
}

\section{Yalan Haberle Mücadele ve İnternet Teyit/Doğrulama Platformları}

\author{
Nurhan Kavaklı (Dr. Öğr. Üyesi) \\ İstanbul Kültür Üniversitesi Sanat ve Tasarım Fakültesi \\ nurhankavakli@gmail.com \\ Orcid: 0000-0002-5003-9996
}

Başvuru Tarihi: 14.08.2018

Yayına Kabul Tarihi: 07.11.2018

Yayınlanma Tarihi: 21.01.2019

\section{Öz}

Günümüzün toplumsal ve siyasal yaşamında, yalan/sahte haber ve yol açtığı olumsuz sonuçlar etkisini daha da fazla hissettiren bir düzeye yükselmiştir. İçinde bulunduğumuz zamanı post-truth bir dönem olarak adlandıran birçoklarına göre, bireyler 'gerçeğin' değerini yitirdiği bu çağda yolunu çok daha kolay kaybedebilir hale gelmiştir. 2016 yılında Birleşik Krallık’ın Avrupa Birliği'nden çıkmasıyla sonuçlanan Brexit referandumu ile Donald Trump'ın kazandığı son Amerika Birleşik Devletleri (ABD) Başkanlık seçimi sürecinde yaşananlar bu duruma verilen örneklerden ikisini oluşturmaktadır. Konuya ilişkin yapılan tartışmalar içinde, yalan haberin artan etkisi ile internetin ve özellikle de sosyal medyanın hayatımıza girişi arasında güçlü bir bağ olduğu ileri sürülmektedir. Bu noktadan hareketle, bu çalışma sosyal medya üzerinden yayılan yalan haberle mücadele yöntemlerini, daha çok gazetecilik pratikleri ile ilişkilendirilerek ele almayı amaçlamaktadır. Amaç doğrultusunda, yalan haberle mücadeleye ve mücadelede önemli bir rol üstlenen internet haber teyit/doğrulama platformlarına odaklanılmıştır. Konuya yönelik ulusal ve uluslararası literatürde yer alan tartışmalar ve yaklaşımlar ışığında, internet haber teyit/doğrulama platformlarının konumu, önemi ve çözüm üretme potansiyeli irdelenmektedir.

Anahtar Kelimeler: Yalan Haber, Haber Doğrulama Platformları, Sosyal Medya, Post-truth, Yurttaş Gazeteciliği, Medya Okuryazarlığı. 


\title{
Dealing with Fake News and Internet Fact-Checking Platforms
}

\author{
Nurhan Kavaklı (Asst. Prof. Dr.) \\ İstanbul Kültür University Faculty of Art and Design \\ nurhankavakli@gmail.com \\ Orcid: 0000-0002-5003-9996
}

Date Received: 14.08 .2018

Date Accepted: 07.11.2018

Date Published: 21.01.2019

\begin{abstract}
In today's social and political life, false news and its consequences have risen to a position that is becoming more and more influential. According to many, individuals are easily getting lost in an age called as a post-truth period in which 'truth' has been lost its importance or value. The two most important events given as examples for this situation are the last US Presidential election won by Donald Trump and the Brexit referendum that resulted in the UK's exit from the European Union in 2016. Among the discussions in this framework, the relation of the growing effect of the false news to the entrance of internet and the social media in our lives, holds an important place. In this concept, this study aims to focus on the ways to deal with false news spreading especially through social media by relating it to the journalistic practices. In this direction, it aims to focus on the internet fact-checking sites which play an important role in fighting fake news. In the light of the debates regarding the issue in international and national literature, the position of the internet factchecking sites, the potential of them to fight against to false news are examined.
\end{abstract}

Keywords: Fake news, Fact-checking Sites, Social Media, Post-truth, Citizen Journalism, Media Literacy. 


\section{Giriş}

Günümüz medya ortamında her geçen gün daha geniş üretim ve yayılım olanaklarına kavuşan yalan/sahte haber, kamuoyunun doğru bilgiyle donanarak sağlıklı bir şekilde oluşabilmesinin önündeki engellerden biri olarak dikkati çekmektedir. Bu durum aynı zamanda kamuoyunu doğru ve tarafsız bir şekilde bilgilendirme işlevini üstlenen basın kurumunun güvenirliği ve geleceği açısından da önem taşımaktadır. İçinde bulunduğumuz dönemi adlandırmak için kullanılan tanımlamalardan biri olan "post-truth" ("gerçek-sonrası"; "gerçek ötesi") kavramı, bu tür haberlerin yol açabileceği olumsuzluklara işaret etmesi açısından önemlidir. Kavramın Oxford Sözlük'teki İngilizce tanımını “Duyguların ya da kişisel inançların nesnel hakikatlerin yerine ya da önüne geçerek, belli bir konu ya da olay hakkında kamuoyunun olușmasında belirleyici hale geldiği durumlar" olarak çevirmek mümkündür. Kavram, bireylerin toplumsal yaşamı anlamlandırması sürecinde gerçeğin ya da hakikat arayışının değer yitirişini, onun yerine kişisel inanışlarla ya da duygularla uyumluluk gösteren sahte "gerçeklerin" güç kazanışını vurgulamaktadır. Ralp Keyes'in 2004 tarihli The Post Truth Era (Hakikat Sonrası Çağ) adlı kitabıyla akademik literatürde kendine yer edinen kavramın, 30 yıl önce gazetecilik akademisyenlerinin tartışmalarında "post factual age" (olgu sonrası çağ) olarak ortaya çıktığı belirtilmektedir (Ettema,1987; Martin, 2017).

"Post-truth" kavramının bilinirliği ise 2016 yılındaki iki gelişmenin ardından hızlı bir şekilde artmıştır. Yalan/sahte haberlerin kamuoyunu yönlendirmedeki etkisini de daha çok tartışılır hale getiren bu gelişmelerden ilki Birleşik Krallık'ın Avrupa Birliği'nden (AB) çıkma kararını oylamak için yapılan ve kamuoyunda BREXIT olarak bilinen referandumdur. $\mathrm{AB}$ aleyhinde üretilen asılsız haberlerin gölgesi altında gerçekleștirilen referandum $A B^{\prime}$ den çıkış kararıyla sonuçlanmıştır. Diğer olayı ise Donald Trump’ın kazandığı Amerika Birleşik Devletleri (ABD) başkanlık seçiminde sosyal medya üzerinden yayılımı hız kazanan yalan haber ve iddialar ve bunların seçim gündemini işgal ederek, seçim sonuçlarını şaibeli kılması (Allcott ve Gentzkow, 2017, 212; Brandtzaeg ve Folstad, 2017, 67) oluşturmaktadır.

Yalan/sahte haber insanlığın tarihi kadar eski bir olgu olmakla birlikte, günümüzde etkisini artırmasının ardındaki en önemli nedenlerden biri olarak yeni medya, özellikle sosyal medya gösterilmektedir. Kavramın "haber raporu gibi görünen, uydurma bilgilere dayalı viral paylaşımlar" (Edson, 2018, 138) şeklindeki tanımlamasında da görüldügü üzere, sosyal medya ile yalan haber arasında yakın bir bağ kurulmaktadır. Bu noktada, sosyal medyanın daha özgürlükçü ve demokratik bir iletişim düzeni için güçlü potansiyel içerdiği öngörülen özelliklerinin manipülasyon amaçlı girişimler için de gündeme getirildiği görülmektedir. Bu özelliklerin başında, sosyal medyanın sıradan kullanıcıları (profesyonel gazeteci vasfı taşımayan) istemeleri halinde haber üreticilerine dönüştürecek şekilde katılımcı ve etkileșimli gazetecilik pratiklerine olanak sağlaması gösterilebilir. Ancak burada sorun olarak görülen temel noktalardan biri, sosyal medyanın kötü niyetli kullanımlarına karşı denetim ya da doğrulama benzeri mekanizmalarının olmayışıdır (Himma-Kadakas, 2017, 27; Pak, 2017, 313). Sosyal medyanın geleneksel medyadan farklı olarak çoklu metinleri (görsel, ses, yazı, video, grafik vb.) içeren haber formatlarına izin vermesi ise manipülasyon yapılabilecek unsurların artmasının ve teyit işlemlerinin güçleşmesinin nedenleri arasında gösterilmektedir (Haigh ve diğerleri, 2017). 
Sosyal medyanın yalan/sahte haberin üretiminin ve dolaşım gücünün artmasında rolünün sorgulanmasına paralel olarak manipülatif haberlerle mücadele ve bu mücadelenin nasıl yapılacağı da önemi artan bir tartışma konusu haline gelmiştir. Özellikle sosyal medyada dolaşıma giren şüpheli haberler için teyit hizmeti sunma amacıyla yola çıkan ve ülkemizde de çeşitli türlerinin uygulamaya geçirildiği internet teyit/doğrulama platformlarının taşıdığı potansiyel, bu bağlamda akademik ilgiyi hak eden bir önem taşımaktadır. Bu platformların yeni medyanın olanaklarını kullanarak bir tür "içeriden" (internetin kendi doğasının olanaklarını kullanarak) mücadele örneğini oluşturması bu organizasyonları daha da dikkate değer kılmaktadır. Bu doğrultuda, sosyal medya üzerinden dolaşıma giren yalan/sahte haberle mücadeleye odaklanan bu çalışmada, yukarıda çizilen kavramsal çerçeve içerisinde, internet haber teyit/doğrulama platformlarının sunduğu olanaklar ve sınırlılıkların ortaya konması amaçlanmaktadır. Çalışmada yanıt aranmaya çalışılan temel soru, internet teyit/platformlarının yalan/sahte haberle mücadelede ne denli etkin bir rol üstlenebileceğidir. Bir derleme makalesi olan bu çalışma, yöntem olarak literatür taramasına dayanmaktadır. Kaynak taraması, Türkçe ve İngilizce bilimsel yayınlarda yer alan konuyla ilişkili çalışmaları kapsamaktadır. Bununla birlikte, kaynak taraması konunun güncel boyutu gözetilerek, güncel gelişmelere ilişkin yetkin kişilerin deneyim ya da gözlemlerini de içeren yazıları da kapsayacak şekilde genişletilmiştir.

Çalışmanın amacı doğrultusunda, ilk olarak sosyal medyanın katkıda bulunduğu 'yeni' iletişim düzeni ile yalan/sahte haberin oluşum koşulları arasındaki bağlantının niteliğini ortaya koyabilmek amacıyla "Sosyal Medyanın Gelişimi ile Yalan/Sahte Haber Arasındaki İlişki" başlıklı bölüme yer verilmiştir. Sosyal medyanın etkisiyle geleneksel haber üretim süreç ve pratiklerinde yaşanmaya başlayan değişime dair tartışmalara da bu bölümde (alt başlıklar altında) değinilmeye çalıșılmıştır. Böylece teyit/doğrulama platformlarının potansiyelinin ve sinırlılıklarının konumlandırabilmesi için bir çerçeve oluşturulmaya çalışılmıştır. Takip eden "Yalan Haberle Mücadele Yöntemleri ve İnternet Haber Doğrulama Platformları" başlıklı bölümde ise ilgili literatürde gündeme getirilen mücadele yöntemleri çeşitli boyutlarıyla ele alınmaya çalışılmıştır. Bu bağlam içerisinde internet teyit/doğrulama platformlarının önemine, potansiyeline ve sınırlarına ışık tutacak tartışmalara yer verilmeye çalışılmıştır.

\section{Sosyal Medyanın Gelişimi ile Yalan/Sahte Haber Arasındaki İlişki}

İnsanları bilgilendirme, eğitme, eğlendirme gibi misyonları olan haber özellikle toplumu ilgilendiren konulara yönelik kamuoyu oluşumunda belirleyici bir rol oynamaktadır (Tokgöz, 2015). Taşıdığı bu değerden dolayı, haber kamuoyunu yönlendirmek isteyen kişi ya da grupların ilgi odağı olmuş, haber adı altında kimi zaman yalan, eksik ya da yanlış bilgi üretimiyle (dezenformasyon) kimi zaman ise gerçek bir bilginin yanlış, eksik ya da taraflı olarak verilmesiyle (misenformasyon) (Tunç, 2010, 248) kamuoyu belli yönlere doğru çekilmeye çalışılmıștır. Kamuoyunu yanlış yönlendirme çabaları ile yalan/sahte haber arasındaki ilişkinin basının ilk dönemlerine, hatta basın öncesi döneme dek uzandığı bilinmektedir (Burkhardt, $2017,5,6)$. Sosyal medyanın ortaya çıkıșı bu ilişkinin yeni bir boyut kazanarak, daha ileri bir aşamaya taşınmasına neden olmuştur (Edson ve diğerleri, 2018, 138). Bu yeni boyutu irdeleyen tartışmalara değinmeden önce yalan haberin çeşitli tanımlamaları olmakla birlikte genel olarak "kasıtlı olarak üretilmiş", "doğru 
olmadığı kanıtlanabilir" ve "okuyucuları yanlış yönlendirebilecek" haber olarak tanımlandığını belirtmek yerinde olacaktır (Allcott ve Gentzkow, 2017, 213). Kavrama ilişkin bir diğer tanımda, yalan haber "kasıtlı olarak yaygınlaștırılan yanlış bilgi" olarak da betimlenmektedir (Himma-Kadakas, 2017, 26).

Haber içeriğinin yanı sıra haberin formatı, sunumu, dağıtımı ve tüketilmesi üzerinde de radikal değişimlere neden olan dijitalleșme yalan/sahte haberin oluşum ve yayılım olanakları için yeni seçeneklerin oluşmasını mümkün kılmıştır. Manipülasyon haber metni üzerinden gerçekleştirilebildiği gibi fotoğraf ya da video gibi görsel metinler üzerinden de kolayca yapılabilir hale gelmiștir. Dolayısıyla bir haber bütünüyle asılsız olabileceği gibi sadece bir bölümü de asılsız olabilir. Manipülasyonların genel olarak politik ve ekonomik olmak üzere iki tür amaçla yapıldığı belirtilmektedir. Ekonomik amaçlı yalan haber üretimi, reklam gelirini yükseltmek amacıyla tıklanma oranını artırmaya dönük nefret, öfke, şaşkınlık gibi duyguları tepkisel olarak harekete geçirmeyi hedeflemektedir (Edson ve diğerleri, 2018, 138). Ekonomik amaçlı olarak sınıflandırılabilecek bir diğer neden telif hakları ihlallerini gizleme çabasıdır. Böyle durumlarda çalıntı habere uydurma bir ek yapılarak, farklı bir haber servis ediliyormuş izlenimi verilmesi söz konusudur (Rubin ve diğerleri, 2015). Politik amaçlı manipülasyonlar ise kitlenin dikkatini belirli bir olaydan uzaklaştırmak ya da belirli bir konuya çekmek için gündem oluşturma amaçlı; kitlelerin belirli konulara ilişkin tutumlarını değiştirmeye dönük olarak propaganda ve ikna amaçlı; kitleyi belirli bir eyleme geçirmek için provokasyon amaçlı olabilmektedir (Korkmaz, 2014, 29-30). Her üç durumda da amaçlanan bir kişinin ya da grubun çıkarını, ününü ya da değerini maksimize etmek ya da başkalarının güvenirliğini ya da değerini düşürerek ününü zedelemek olabilir.

Ancak bazı durumlarda güvenirliği yüksek kaynaklar tarafından da kötü niyet taşımayan amaçlarla da uydurma haber üretimi söz konusu olabilmektedir. Örneğin, ABD'de yayınlanan Muse adlı magazin dergisinin bilim ve teknik ekinde okuyucuların tahmin ederek, bulabilmeleri amacıyla için uydurma bir haber yayınlanmaktadır. Bu haberlerin gerçek olmadığını fark edebilmek ise, özellikle bağlamından kopartılarak yayınlandığında, oldukça zorlaşabilmektedir (Rubin ve diğerleri, 2015). Benzer şekilde, her ne kadar kamuoyunu kasıtlı olarak yanlış yönlendirmek gibi bir amaç taşımasa da sonuçta bu yönde bir etki yapabilen eğlence amaçlı üretilmiş haberlerin ya da bu tür haberleri üreten oluşumların bulunduğunu da belirtmek gerekmektedir. Türkiye'de eğlendirmek amacıyla uydurma haberler yapan Zaytung adlı oluşum buna bir örnek olarak verilebilir. Bu tür sitelerin haberleri inanılmayacak derecede absürt olsa da zaman zaman bu haberleri gerçek sanarak yer veren ciddi haber kuruluşları da olabilmektedir. Manipülatif enformasyon üretimi bireyler ya da bazı sivil kolektifler tarafından yapılabildiği gibi kendi ülkesindeki ya da başka bir ülkedeki siyasi gelişmeleri etkilemek isteyen devletler tarafından da yapılabilmektedir (Haigh ve diğerleri, 2017).

Yalan haberin etki alanının geçmişte hiç olmadığı kadar genişlemesinin yolunu açan teknolojik gelişme ise interaktif bir iletişim düzenine olanak sağlayan Web 2.0 teknolojisi olmuştur. Okuyucunun haber karşısındaki konumlanışını pasiften aktife dönüştüren Web 2.0 teknolojisi sayesinde kullanıcılar internet üzerindeki içerik üretime doğrudan katılabilir hale gelmiştir. Yine Web 2.0 teknolojisi, üzerinde yükselen sosyal medya aracılığıyla kullanıcılar arasında kolaylıkla el değiștirebilen ve değiştirilebilen bir içerik oluşumu gerçekleşmeye başlamıștır. Bu sayede, herhangi 
bir profesyonel deneyimi ya da tanınırlığı olmayan bireysel bir kullanıcının dahi CNN gibi dev medya kuruluşlarının ulaşabileceği büyüklükte kitleye ulaşabilmesi de mümkün hale gelmiştir (Allcott ve Gentzkow, 2017, 211).

Diğer yandan kullanıcı türevli ve etkileşimli içerik üretimini, profesyonel medya mensuplarının ya da kurumlarının hâkimiyetinin güç kaybettiği bir dönemin kapısını aralayarak, 'katılımcı kültür toplumunun' ortaya çıkmasına yol açacağı nedeniyle olumlu karşılayan yaklaşımlar da bulunmaktadır. Böylece, uzmanlık paradigmasının gücünü yitireceği ya da ucu açık bir iletişim sürecine evrileceği bu yeni dönemde, etki dereceleri arasında farklılar olsa da herkesin bir katılımcıya dönüşebilmesinin mümkün olacağı öngörülmektedir (Jenkins, 2006, 52, 53, 132). Bu süreçte Facebook, Twitter, Youtube gibi yeni medyanın bir getirisi olan sosyal medya oluşumları, vatandaşlarca üretilen haberlerin kamuoyuyla paylaşıldığı mecralar olarak anılmaktadır. Yeni medyanın katılımı güçlendirme potansiyeline işaret eden bu durum, bilgi üretimi ve tüketiminin demokratikleşmesi ve alternatif haber kaynaklarının gelişmesi adına olumlu bir gelişme olarak değerlendirilmektedir. Aynı zamanda dezavantajlı toplumsal kesimlerin basında temsil kazanması ve seslerini duyurabilmesi adına da olumlu karşılanmaktadır (Çetin, 2015, 64).

Ancak diğer yandan zaman ve mekân sınırlarının aşıldığı, iletişimin küreselleştiği yeni düzende dünyanın farklı yerlerinden bağlanılabilen kullanıcılar tarafından sürekli bir akış halinde dolaşıma çıkarılan bilginin teyit edilmesindeki güçlük, sosyal medyanın yarattığı iletişim alanının şaibeli hale gelmesine neden olmuştur (Brandtzaeg ve Folstad, 2017; Pak, 2017). Geleneksel medyada geçerli olan teyit etme süzgeçlerine tabii olmayan bu iletişim alanı, kendi savlarını güçlendirmek ya da kamuoyunu kendi çıkarları doğrultusunda yönlendirmek isteyen kişi ya da grupların manipülatif haber üretimi ve dağıtımı için de cazip bir alan haline dönüştürmüştür. Sosyal medyaya yönelik endişelerin geçerlilik payı taşıdığı, yapılan bazı araştırmaların sonuçlarında da ortaya konmaktadır. Örneğin, ABD'de sosyal medya kullanıcıları üzerine yapılan bir araștırma 2012 yılında kullanıcıların yüzde 49'unun sosyal medya üzerinden yalan haber aldığını göstermektedir. 2015 yılında yapılan başka bir araştırmada da söylenti ve yanlış bilginin sosyal medya nedeniyle önceki dönemlere göre çok daha geniş bir alana ve çok daha hızlı bir şekilde yayıldığı belirtilmektedir (Brandtzaeg ve Folstad, 2017, 65). Buzzfeed adlı haber sitesi tarafından gerçekleştiren bir analiz ise ABD başkanlık seçimlerinde seçimle ilgili uydurulmuş yalan haberlerin Facebook'un üzerinden yayılım oranının, geleneksel haber kanal haberlerinden verilen seçim haberlerine oranla çok daha yüksek olduğunu göstermektedir. Manipülatif enformasyonun özellikle ani gelișen olaylar, siyasal kargașalar ya da panik durumlarında daha da arttığı gözlenmiştir (Silverman, 2016).

Sosyal medya yalan haberlerin yayılımına hız ve artış katmasının yanı sıra yarattığı filtre baloncukları ve yankı odaları ile de manipülatif bilginin güç kazanmasının altyapısını hazırladığı için sorumlu tutulmaktadır (Thorson, 2016; Flaxman ve diğerleri, 2016). Yankı odaları ile filtre baloncukları, internet sitelerinin ya da sosyal medyanın kullandıkları algoritmalar nedeniyle, kişilerin internetteki faaliyetlerine ya da eğilimlerine göre seçenekler sunması ya da 'kapalı' alanlar kurmasını sağlaması ve bunun sonucunda bireylerin sürekli benzer doğrultuda haber, bilgi ve düşüncelerin bir iletișimin içinde kalması olarak tanımlanabilir. Örneğin Facebook, kullanıcılarının ilgisini çekebilecek ve etkileşime girebilecekleri türden içerikleri 
sunmak üzere tasarlanmış bir algoritmaya sahiptir. Algoritmanın filtrelediği içerikler tek yönlü olduğu için ortaya çıkan filtre baloncuğu nedeniyle kullanıcılar çoğunlukla zaman tünellerinde kendi görüşlerine uygun içeriklerle karşılaşmaktadırlar. Bunun sonucunda karşıt ya da farklı fikirlerden haberdar olmaları güçleşmektedir. Birçok seçenek olmasına karşın insanların kendi düşünce ve inançlarıyla uyumlu olan içeriği tüketme ve benzer düşüncedeki insanlarla arkadaş olma eğilimde olması ise sosyal medyada ideolojik ayrışmalara yol açan yankı odalarının artmasına neden olabilmektedir. Yankı odalarında paylaşılan bir haber yanlış olsa dahi o haberi paylaşan kişiyle benzer eğilimde olan diğer kişilerin bu haberi doğru kabul etme olasılığı yüksek olmaktadır. Diğer yandan kullanıcıların doğru olmayan bilgileri ya da kişisel görüşlerini herhangi bir doğrulama süzgeciyle karşılaşmadan rahatlıkla paylaşabilmesi sosyal medyanın duyguların ya da inançların hakikat üzerinde hâkimiyet kurmasının yanı sıra, doğru olmayan enformasyonun etkisini büyütmesiyle kamuoyunu yanlış yönlendirilmesine yol açabilmektedir (Flaxman ve diğerleri, 2016, 299).

Sosyal medyanın hedef tahtasına oturtulması, yalan haberle mücadelede sorumluluğun sosyal medya şirketlerince de üstlenilmesi gerektiği tartışmasını da beraberinde getirmiştir. Rus trollerin ürettikleri sahte haberlerle sosyal medya özellikle de Facebook üzerinden 2016 ABD başkanlık seçimine yönelik bir kampanya yürüttüğü ve 150 milyon Amerikalıya ulaștığı iddiası, Facebook'u konuyla ilgili çeşitli önlemler almaya itmiştir. Şirket 2017 Sonbaharından başlayarak çeşitli teknolojik uygulamaların yanı sıra uluslararası bağımsız teyit/doğrulama platformlarıyla işbirliğini de kapsayan teyit programları başlatmıştır. Teyit işleminden geçemeyen haberler Facebook News Feed'de aşağı sıralara indirilerek, bu haberleri içeren sayfaların dolaşımı azaltılarak, dezenformasyon ya da misenformasyon mecrasına dönüșen sosyal medyada yalan/sahte haberin etkisi düşürülmeye çalışılmaktadır (Perez, 2018). Ancak, burada da enformasyon hacminin büyüklüğü, teyit işleminin zorluğu ve uzun zaman alması, teknolojinin yalan haberin lehine bir işleyișe daha yatkın olması (yalan haberin çok hızlı ve geometrik şekilde yayılabilmesi) gibi sorunlar varlığını sürdürmektedir.

Aşağıda konuya ilişkin tartışmalar ışığında, yalan haber ve enformasyonun sosyal medya üzerinden üretimi ve yaygınlaştırılmasının dinamikleri, bu dinamiklerin gazetecilik pratikleri ile ilişkilendirilerek daha geniş bir şekilde ele alınmaya çalışılacaktır.

\subsection{Sosyal Medya Üzerinden Yalan/Sahte Haber Üretimi ve Gazetecilik Pratiklerinin Rolü}

Yalan/sahte haberin üretim ve dağıtımın yaygınlaşmasında çeşitli gazetecilik pratiklerinin önemli bir rol oynadığı ileri sürülmektedir. Bu tür pratiklerin her zaman kasıtlı olarak gerçekleştirilmese de sonuçta eksik ya da yanlış enformasyon lehine bir akışa neden olarak, kamuoyunun yanlış yönlendirilmesine yol açtığı için eleştiri konusu yapıldığı görülmektedir. Bu yöndeki eleștiri ve tartışmalar "yurttaş gazeteciliği" ve "profesyonel gazetecilerin sosyal medyayı haber kaynağı olarak kullanması” başlıkları altında toplanarak, aşağıda ele alınmaya çalışılmıștır.

\subsubsection{Yurttaş Gazeteciliği}

Çeşitli tanımlamaları olmakla birlikte yurttaş gazeteciliğini, gazetecilikle profesyonel olarak ilgili olmayan kişilerin haber üretim sürecine çeşitli şekillerde dahil olduğu gazetecilik pratiği șeklinde tanımlamak mümkündür. İlk olarak 1990'larda ABD’de 
uygulanmaya başlayan yurttaş gazeteciliğinin ortaya çıkış nedenine dair farklı görüşler ve bu görüşler doğrultusunda oluşturulmuş çeşitli tanımları bulunmaktadır. Bunlardan birinde, yurttaş gazeteciliği ana akım medya kuruluşlarının ticari kaygılar nedeniyle (azalan okuyucusunu yeniden kazanmak amacıyla) kendi ticari içerik üretimi süreçlerini kullanıcıların katılımına açma yoluna gitmeleri olarak tanımlanmıştır (Uzun, 2010, 260). Diğer bir tanımda ise yurttaş gazeteciliği, yine ana akım medya kurumlarının aşırı ticarileşmesi sonucu, asıl görevi olan kamu yararını gözetmekten uzaklaşmasının yarattığı güvenilirlik sorununu çözmek, toplumla yeniden bağ kurmak ve "gazeteciliğin eski altın günlerine dönülmesini" hedeflemek olarak tanımlanmaktadır (Alankuş, 2008, 14).

Ortaya çıkışında profesyonel medya kuruluşlarının söz sahibi olduğu bu yeni gazetecilik uygulaması, internetin ve devamında sosyal medyanın gelişimi ile birlikte, kontrolün kısmen ya da tamamen yurttaşların eline geçtiği bir gazetecilik pratiğine dönüștüğü görülmektedir. Günümüzde yurttaş gazeteciliğin taşıdığı asıl anlamın "içerik üretim sürecini profesyonellerin ellerinden alan, üretimin bireyler tarafından yapıldığı, ticari medya kuruluşlarından bağımsız uygulamalar” olduğu belirtilmektedir (Başaran, 2010, 260). Bu noktada yurttaş gazeteciliğinin "medya girişimlerinin kar etme amaçlarından kaynaklanan yapısal sınırlamalarıgöze almayan bir girișim" (Uzun, 2006, 633) olarak algılandığı görülmektedir. Ancak, diğer yandan günümüzde, kullanıcıların haber üretim sürecindeki konumlanışlarına ya da haber yapma motivasyonlarına dair farklılıkları imleyen katılımcı gazetecilik, etkileşimli gazetecilik, kamu gazeteciliği (Nip, 2006) ya da tanık gazeteciği (tesadüfen tanık olunan bir olayı haberleștirilmesi) (İrvan, 2017) gibi gazetecilik pratiklerinin de yurttaş gazeteciliği kavramı altında algılandığı görülmektedir. Yurttaş gazeteciliğinin önde gelen destekçilerinden olan Dan Gillmor da haber içeriğinin yurttaştan gelmesi nedeniyle, katılımcı gazetecilik yerine yurttaş gazeteciliğinin kullanılması gerektiğini savunur (Gillmor, 2006). Tanımı üzerinde çeşitli tartışmalar bulunsa da yurttaş gazeteciliği kavramı genel olarak "asıl mesleği gazetecilik olmayan yurttaşların dijital iletişim teknolojileri yardımıyla haber üretim sürecine katılmaları" șeklinde ele alınmaktadır (İrvan, 2017). Tanımında farklılıklar olsa da günümüzde yurttaş gazeteciliğine yaygın olarak sosyal medya üzerinden gerçekleştirilen bir gazetecilik pratiği olarak yaklaşıldığını söylemek yanlış olmayacaktır.

Kullanıcı türevli içeriğe olanak sağlayan Web 2.0 teknolojisine paralel olarak bireysel dijital video ve görsel üretimini ve paylaşımını olanaklı kılan akıllı telefonlar sayesinde yurttaş gazeteciler kolaylıkla haber üretebilir hale gelmişlerdir. Sosyal yaşam pratikleri eş zamanlı paylaşma olanağı sunan ve sosyal yaşamın vazgeçilmez bir parçası haline dönüşen sosyal medya (Ișıklar, 2017) platformları da haberlerin kolaylıkla geniş kitlelere ulaştırılabileceği alternatif kanalları oluşturmuştur. Yurttaş gazeteciliği bireysel düzeyde gerçekleştirilebildiği gibi, küçük bir grup ya da kâr amacı gütmeyen organizasyonlar ya da yurttaş gazeteciliği kolektifleri tarafından da yapılmaktadır. Geleneksel medya kurumlarının haber üretim ve dağıtım sürecindeki egemenliğini sarsarak, sürecin demokratik bir nitelik kazanmasına yaptığı katkı açısından yurttaş gazeteciliğinin önemi büyüktür. Profesyonel gazetecilerin yurttaş gazeteciliğe dair değerlendirilmelerini içeren akademik bir çalışmada, görüşü alınan bir gazeteci "mevcut medya sahipliği ikliminde vatandaşların gerçek bilgiye en dolaysız şekilde yurttaş gazetecileri üzerinden ulaşılabileceğini” ifade etmektedir (Devran ve Özcan, 2017, 159). Yurttaş gazeteciliğinin önemi, özellikle geleneksel 
medyanın tekelci bir yapılanma eğilimi gösterdiği ya da basının sansür baskısı altında olduğu sistemlerde kamuoyuna bilgi akışının sağlanmasına yaptığı katkı nedeniyle daha da artmaktadır.

Diğer yandan manipülatif haberlerin yaygınlık kazanması yurttaş gazeteciler tarafından üretilen haberlerin güvenirliğine dair kuşkular ve çekincelerin oluşmasına yo açmıştır. Yurttaş gazetecilerin, mesleğinin etik ilkelerini edinebilecekleri bir eğitim sürecinden geçmemiş olmaları nedeniyle "kaynak doğrulama" ve "haberi doğrulama" gibi zorunluluklarının ve aynı zamanda meslekle ilgili yasal sorumluluklarının olmaması çekincelerden birini oluşturmaktadır (Rubin ve diğerleri, 2015). Diğer bir çekince konusu ise yurttaş gazetecilerin "içerikleri kendi çıkarları doğrultusunda değiştirebileceği” ve "haberi toplumda belli manipülasyonlar için şekillendirebileceği” yönündedir. Profesyonel gazetecilikte, gerçeğe sadık kalınabilmesi için gerekli görülen haberdeki "tarafsızlık" ve "doğruluk" unsurlarının zedelenmesine işaret etmesi açısından da bu tartışmalara önem atfedilmektedir (Devran ve Özcan, 2017, 171).

Tartışmaları, temel birçok meslek pratiğinin değişmesine yol açan dijital gazetecilikle birlikte, "gazetecilik", "gazeteci", "haberde doğruluk/tarafsızlık" gibi kavramlara dair tanım ya da yaklaşımların da farklılaşmak zorunda kalışıyla ilişkilendirmek mümkündür. Gazeteciliği, genel olarak, olguya/gerçeğe dayandırılmış güncel bilgiyi sağlayan bir sistem, gazetecileri de bu tür bilgi sağlama işlevini üstlenen unsurlar olarak ele alan geleneksel yaklaşımlar farklı açılardan yetersiz kalmakla eleştirilmektedir. Yeni yaklaşımların birçoğunun temel olarak, gazeteciliğin ve gazetecinin işlevini dijital ortamdaki güncel pratiklerine göre yeniden ele almak gerekliliği noktasından hareket ettiği söylenebilir (Himma-Kadakas, 2017, 27). Haber üretim sürecinin geleneksel haber odalarının dışına, aralarında sosyal medyanın da yer aldığı, dijital platformlara dek genişlemesi bu değişimin ana nedenlerinden birisi olarak ele alınmaktadır. Gazetecinin gerçeğe/olguya dayalı "bilgi sağlama" işlevi, dijital ağlarla birbirine bağlı sayısız aktörün de bilgi sağlayıcı konumu kazanmasıyla birlikte daha da sorgulanır hale gelmiștir. Haber kaynakları arasına devasa bilginin aktığı dijital kaynakların eklenmesiyle, gazetecinin bilgiyi doğrulamak için gerekli zaman ve araçlardan yoksun hale geldiğini vurgulanmaktadır. Bu doğrultuda, gazetecinin doğru bilgiyi seçen ya da temin eden değil, toplum için uygun olabilecek bilginin ne olduğunu seçen ve bu bilgiyi işleyen kişiye dönüştüğü belirtilmektedir (Himma-Kadakas ve Palmiste, 2017).

Diğer yandan profesyonel gazetecilik için öngörülen tarafsız haberciliğin tam olarak sağlanmasının geleneksel gazetecilik için de zaten tartışmalı olduğunu ileri süren görüşler, konuya farklı bir perspektif sunmaktadır. Profesyonel gazetecileri özünde "yorumlayıcı bir topluluk" olarak gören yaklaşımlardan hareket edilerek, yurttaş gazeteciler de benzer bir topluluk olarak değerlendirilmektedir. Her yorumlayıcı topluluk gibi profesyonel gazeteciler de normlar ve kriterler (hakikat, kamuya sadakat, disiplinli bir doğrulama faaliyeti, bağımsızlık, titizlik, etkileşim, önem ve ilgililik) geliştirmişlerdir. Profesyonel gazetecilerin geliștirdikleri norm ve kriterler "işlevsel gerçekliği” öne çıkarmaktadır. Diğer bir "yorumlayıcı topluluk" olan yurttaş gazeteciler ise geliştirdikleri norm ve ilkeler (diyalog, işbirliği, gayrı-resmi kaynaklara başvurmak vb.) ile "diyalojik gerçekliğini” öne çıkarmaktadır (Saka, 2015, 260). 


\subsubsection{Profesyonel Gazetecilerin Sosyal Medyayı Haber Kaynağı Olarak Kullanması}

Çok sayıda gönüllü kullanıcı tarafından üretilen içeriğin dinamik yapısı kısa zamanda sosyal medyanın profesyonel gazeteciler için de bir haber kaynağına dönüşmesine neden olmuştur. Sosyal medyanın hem sıradan yurttaşlar hem de profesyonel gazeteciler için önemli haber kaynaklarından biri haline gelmesi ise iki yönlü bir etkileşimin gelişmesini de beraberinde getirmiştir; profesyonel gazeteciler kendi üretimleri için beslenip, yararlanabilecekleri ancak diğer yandan da rekabet etmek zorunda kaldıkları ve güvenirliğinden hiç bir zaman tam olarak emin olamayacakları bir kaynakla ilişkiye girmek zorunda kalmışlardır. Yapılan bazı araştırmalar profesyonel gazetecilerin sosyal medya kaynaklı haberlerin doğruluğuna şüpheyle yaklaşmalarına rağmen, sosyal medyayı güncel gelişmeleri takip etmek, yeni haber konuları bulmak, habere tanıklık eden veya sosyal medyada haberi ilk duyuran kaynaklara ulaşmak amacıyla yaygın șekilde kullanılmakta olduğunu göstermektedir (Taşkıran ve Kırık 2016; Devran ve Özcan, 2017).

Diğer yandan, profesyonel basın mensuplarının sosyal medyadaki içeriği yaygın olarak kullanmalarına rağmen teyit işleminin karmaşık ve zor bir süreç olması nedeniyle yeterli bir kontrol mekanizması geliştirebilmeleri mümkün olmamaktadır. Teyit işlemini zorlaştıran nedenler arasında içerik üretiminin gerçek zamanlı olması, içerik miktarının büyüklüğü, orijinal kaynakların tespitinin ya da ulaşılabilirliğinin zorluğu, metinlerin çok farklı biçim ve tarzda olması yer almaktadır. Günümüzde, akıllı telefonlar aracılığıyla bile çoklu haber unsurlarının (fotoğraf, video, çizim, ses, metin vb.) bir arada kullanıldığı haber üretimi gerçekleștirilebilmektedir. Dolayısıyla, orijinal metinler üzerinde manipülatif değişikliklerin yapılıp yapılmadığının kontrolünün yanı sıra haberde kullanılan tüm unsurların tek tek kontrolünün güçlüğü de profesyonel gazetecilerin işlerini daha da zorlaştırmaktadır. Bu ve benzeri güçlüklerin yanı sıra sayısız kullanıcı tarafından üretilen enformasyonun kesintisiz bir şekilde aktığı yeni medya ortamı profesyonel gazeteciler için rekabet koşullarını daha da zorlu hale getirmiştir. Haber atlamamak uğruna 'haber doğrulama' aşamasının gereği gibi yapılamaması, hatta tamamıyla devreden çıkarılması söz konusu olabilmektedir (Martin, 2017, 45, 47).

Geleneksel gazetecilikte gazeteci yaptığı haberin doğruluğunu test etmek için haber kaynağından aldığı bilgiyi, bir başka kaynaktan doğrulatma yoluna gitmektedir. $\mathrm{Bu}$ doğrulatma işlemi gazetecinin elindeki haberin doğruluğundan emin oluncaya kadar birkaç kez tekrarlanabilmektedir. Profesyonel gazeteci kendisinin, temsil ettiği kurumun ve aynı zamanda mesleğin itibarını koruma sorumluluğuyla hareket etmek zorundadır. Benzer kaygılar rakip kurumlardaki diğer gazeteciler için de geçerlidir. Ancak, dağıtıma soktuğu habere ilişkin bu tür sorumlulukları olmayan ve çoğu durumda bu yönde farkındalıklar bile taşımayan kullanıcılar profesyonel gazetecilerden çok daha hızlı ve rahat hareket edebildikleri bir ortama sahip olmuşlardır. Böylece, profesyonel gazetecilerin sosyal medyayı haber kaynağı olarak kullanmaları ve aynı zamanda onunla rekabet etmeleri sonucunda yaşanan etkileșim, sosyal medya üzerinde yayılan yalan haberlerin geleneksel medya aracılığıyla da etkisini güçlendirmesinin yolunu açmıştır (Devran ve Özcan; 2017, 163).

\section{Yalan Haberle Mücadele ve İnternet Teyit/Doğrulama Platformları}

Sosyal medya üzerinden yayılan yalan haberlerin yol açabileceği sorunlar karşısında gerek akademik çevrelerden gerekse alanın uygulayıcılarından mücadele 
konusunda tepkisel yaklaşımları da barındıran öneriler geliştirilebilmektedir. Bunlardan biri bu tür enformasyonun internetten kaldırılması yönündedir. Ancak, hassas bir șekilde düzenlenmiş uygun politikalar oluşturulmadan yapılacak bu yöndeki uygulamalar, özgür haber alma kaynaklarının başında gelen internete yönelik sansür uygulamalarına yeşil ışı yakma riski taşıması nedeniyle sakıncalı bulunmaktadır (Cerf, 2017, 9). İnternetin katılımı ve alternatif haber kaynaklarını teşvik eden yapısının önemi dikkate alındığında, nefret söylemi, şiddet içeren içerikler, çocukların cinsel istismarı (Binark, 2010; Kavaklı, 2018) gibi sakıncaları tartışma götürmeyen istisnalar dışında bu tür önlemlerin tercih edilmesinin sakıncalı olacağı ortadadır. Diğer yandan, sosyal medya üzerinden akan enformasyon miktarının devasa büyüklüğü ve akış hızı böyle bir önlemin sağlıklı bir şekilde uygulanabilirliğini güç kılmaktadır. Önerilen bir başka yöntem ise, insanlara yorumlardan çok olgulara (gerçekten ne olup bittiğinin doğrulanabilir verilerine) dayalı doğru bilgilerin sağlanmasını destekleyici politikaların uygulanmaya konması yönündedir (Cerf, 2017, 9). Adı yalan/sahte haberle birlikte sıklıkla anılan post-truth kavramının, insanların kararlarını verirken nesnel hakikatlerden çok kişisel duygu ve inançlarının, dolayısıyla bunlarla uyuşan yorumların etkisinde kalmasıyla olan ilişkisi düşünüldügünde bu yaklaşım anlamlı görünmektedir. Ancak diğer yandan, Jurgen Habermas'ın (1999) kamusal alan yaklaşımından hareketle, kamusal alanın (ideal olarak) farklı ya da rakip görüşlerin karşılaştığı, birbiriyle etkileşim haline girdiği, çarpışarak, tartışarak ya da uzlaşarak birbirini dönüștürebildiği bir diyalog ve müzakere alanı olduğu akılda tutulduğunda nesnel olguların yanı sıra "yorumların" da demokratik bir iletişim düzeni için önemli olduğu görülecektir. Yorumların demokratik bir iletişim düzenindeki yerini teslim etmekle birlikte, kişilerin doğru bilgiye dayalı yorumlar üretebilmesi ya da karşılaştıkları yorumlardaki bilgileri doğrulatmak gereği duyduklarında doğru bilgilerin erişebilir olmasının önemini de belirtilmek gerekir.

Yalan haber üretimi ve dolaşımındaki artışın post-truth bir dönemin oluşmasında etkisi büyük olmakla birlikte, diğer önemli unsur, kişilerin kendi görüş ve inançlarına sıkı sıkı sarılmak adına yalan ya da yanlış bilgiler içeren yorumlara inanmaları, yorumu hakikat sanmaları ya da kendilerini farklı görüşlere kapatmalarıdır. Bu noktada kullanıcılara yalan haberlere karşı eleștirel yaklaşma alışkanlığı kazandıracak bir mücadele yöntemi olarak medya okuryazarlığı karşımıza çıkmaktadır. Medya okuryazarlığının önemi ve gereği sadece akademik çevreler tarafından değil, medya profesyonelleri tarafından kabul görmektedir. Yurttaş gazeteciliğinin sunduğu olanaklara ve içerdiği risklere odaklanan akademik bir çalışma kapsamında görüşülen bir basın çalışanı, kullanıcıların internet üzerindeki içeriğe karşı dikkatli olmalarını ve gerektiğinde doğruluğunu sorgulamalarını sağlayacak becerileri kazanmalarında medya okuryazarlığının önemini şu sözlerle vurgulamaktadır:

\footnotetext{
"Haber ve bilgilerin doğruluğunu aslında geleneksel medyada daha doğru tespit edebiliriz. Bir Google araması veya fotoğrafın kaynă̆ının tespit edilmesi çok şeyi değiștirir; ama olağanüstü durumlarda sosyal medyada bilgi akışı oldukça hızlıdır, bu durum bazen bilgi akışlarının kirliliğine neden olmaktadır. İnternet kullanıcıları kriz anında her bilgiye inanmak isterler bu nedenle bunun önüne geçebilmek için bilinçli medya okuryazarı olmak gerekmektedir" (Devran ve Özcan, 2017, 165).
}

Burada medya okuryazarlığının sadece korumacı ya da sakınmacı türden önlem ve beceri geliştirilmesine indirgenmemesi gerektiğine dair görüşlerin altını çizmek 
gerekmektedir. Mutlu Binark ve Mine Gencel Bek'in (2010, 219) önemine değindiği bu görüşler temel olarak, internetin demokratik katılımı güçlendirici potansiyelini destekleyici şekilde, eleştirel medya okuryazarlığı ile katılımcı yurttaşlık arasında bir bağ kurulmasının gerekliliğini vurgulamaktadır. Böylece kullanıcılar gerek karşılarına çıkan metinleri anlamlandırırken, gerekse kendi metinlerini üretirken, yeni medyanın pazar ekonomisine dayalı ekonomi-politik yapılanması, metinlerin nasıl ve hangi amaçlarla üretilmiş olabileceği, metinlerin üretildiği ve tüketildiği toplumsal yapıdaki, ekonomik, siyasal ve kültürel bağlamlar konusunda bilinçli olacaklardır. Ancak medya okuryazarlığında (taşıdığı tüm olumlu potansiyele rağmen) günümüzde sadece okul çağında olan bir nüfusa odaklanan ve belirli bir zamana yayılan eğitimsel bir yaklaşım olmasından dolayı kısıtlılıklar söz konusudur. Ek olarak, yalan haberin ve söylentilerin sosyal medya üzerinden çok hızlı bir şekilde yayılabildiği göz önüne alındığında kullanıcıların bunlara şüpheyle yaklaşsa bile doğruluğunu kontrol edebileceği teyit mekanizmalarına gereksinim vardır. Bu gereksinimin karşılanması, bir haberin doğru ya da yanlış olduğuna dair çatışmalı görüşlerin söz konusu olduğu ve kafa karışıklığının yaşandığı durumlarda daha da işlevsel hale gelmektedir.

Genel olarak "birincil ve ikincil kaynakların araştırılması aracılığıyla, kamuya yönelik bilgilendirmelerde yer alan iddiaların kontrolüne" yönelik hizmet sunan servisler olarak tanımlayabileceğimiz internet haber doğrulama platformları, bu ihtiyacı karşılamak üzere ortaya çıkan yapılanmalardan biridir. (Brandtzaeg ve Folstad, 2017, 65). İlk olarak 2000'lerin ilk yıllarında ve daha çok siyasi demeçlerin ve haberlerin teyidine yönelik olarak ABD'de kurulan ve ardından diğer ülkelere yayılan internet haber teyit/doğrulama platformlarının sayısı 2016 tarihli bir kaynakta 113 olarak verilmektedir ve bu tür organizasyonların son 10 yıla yakın bir zaman içinde 50'den fazla ülkeye yayıldığı belirtilmektedir (Graves ve Cherubini, 2016, 6). Başka bir kaynağa göre teyit/doğrulama platformlarının tarihini 1980'lere Ronald Reagan'ın ABD başkanlık kampanyasına dek geri götürmek mümkündür (Lowrey, 2015, 377). Siyasal seçimlerde yürütülen halkla ilişkiler kampanyalarında medyayı ve kamuoyunu manipüle etmeye dönük haberlerin oluşturulmaya başlanması ve bu tür pratiklerin giderek geleneksel habercilik kanallarını devre dışı bırakıp kendi rutinini oluşturması, profesyonel gazetecilerde haberler üzerindeki kontrolü kaybettiklerine dair endişelere yol açmıştır. Artan endişelerin giderilmesi amacıyla kurumların kendi bünyelerinde haber doğrulama mekanizmaları oluşturulmaya başlanmıştır. İnternet teyit/ doğrulama platformlarının dayandırıldığı diğer bir kaynak olarak şaka ya da kandırma amaçlı üretilen asılsız haberleri doğrulamak amacıyla 1990’larda ortaya çıkan ve "hoax-busting" (palavra-avcısı) diye bilinen siteler de gösterilmektedir (Lowrey, 2015, 377). Günümüzde her iki türü de bünyesinde toplayan internet teyit/doğrulama organizasyonları bulunmaktadır.

Günümüzde çeşitli gazetecilik örgütleriyle bağlantılı olarak çalışan ya da "doğru haber alma hakkını" gözetmek (Yegen, 2018) gibi kamu hizmeti amacıyla ve kâr amacı gütmeden bağımsız bir girişim ya da bir STK projesi olarak hizmet sunan internet teyit/doğrulama platformlarını ilgi alanlarına göre üç kategori altında toplamak mümkündür (Brandtzaeg ve Folstad, 2017, 65):

- Çevrimiçi söylenti ve asılsız haber ya da hikayelere odaklananlar (örn. Snopes. com., Hoax-Slayer, HoaxBusters, ThruthOrFiction.com., Viralgranskaren-Metro) 
- Politik ve kamusal beyanlara odaklananlar (örn. FactCheck.org, PolitiFact, The Washington Post Fact Checker, CNN Reality Check, Full Fact)

- Belirlikonularya dabelirliçatışmalarüzerine odaklananlar(örn.\#RefugeeCheck, Climate Feedback, StopeFake, TruthBe Told).

Ülkemizde internet haber teyit/doğrulama platformlarının tarihi ise göreceli olarak yenidir. $\mathrm{Bu}$ alandaki ilk girişim olarak gösterilebilecek doğrulukpayi. com, Ortak Gelecek İçin Diyalog Derneği'nin bir girişimi olarak 2013 yılında kurulmuştur (http://www.dogrulukpayi.com/). Politikacıların demeçlerinin doğruluğunu ölçmek amacını taşıyan doğrulukpayi.com, bu haliyle yukarıdaki ikinci kategoriye yakın durmaktadır. Türkiye'nin ilkleri arasında yer verilebilecek olan Malumatfuruş'un tarihi ise 2015'e uzanmaktadır (Yeğen, 2018). "Köşe yazarlarını yanlışlama girişimi" (http://www.malumatfurus.org/hakkinda/) olarak kendini tanıtan Malumatfuruş da ikinci kategoriye yakın durmaktadır. Teyit Medya Araştırmaları tarafından bağımsız bir girişim olarak 2016 yılında kurulan ve amacını "yaygın bilinen yanlışlardan, sosyal medyanın gündemine oturan şüpheli bilgilere, yaygın medyanın gündeme getirdiği iddialardan, şehir efsanelerine birçok alanda doğrulama yaparak okurun süzgeçten geçirilmiş bilgiye ulaşması" (https://teyit. org/) şeklinde belirten teyit.org ise yukarıda birinci sırada verilen kategoriye yakın durmaktadır. Aynı kategori içinde değerlendirebileceğimiz diğer bir site dogrula. org.'dur (https://dogrula.org/). Oluşumun Facebook sayfasındaki "hakkımızda" bölümünde "İnternet üzerinden provokasyon amaçlı yapılan yalan haberlerin tespiti ve doğru bilgi paylaşımı yapmak üzere kurulmuştur” açıklaması bulunmaktadır. Ancak, sahiplik ya da finans kaynaklarına ilişkin bilgiye verilmemiştir (https:// www.facebook.com/dogrula.org/). "Şüpheli ve temelsiz iddiaları irdelemek" amacı taşıyan ve gönüllü çalışanlardan oluşan Yalansavar (https://yalansavar. org/) ile Harvard Üniversitesi'nde okuyan bir grup Türk öğrencinin kurduğu Bilim Kazanı (https://bilimkazani.org/) adlı oluşumlar ise üçüncü kategoriye daha yakın durmaktadır. İnternet doğrulama platformlarının çalışma (doğrulama) yöntemleri konularına göre farklılık göstermekle birlikte temel olarak internet üzerinden gerçekleştirilmedir. Örneğin teyit.org teyit interneti taramak suretiyle seçtikleri şüpheli haberleri, virallik ya da aciliyet durumlarına öncelendirerek doğrulama işlemine tabi tutmaktadır. Doğrulama işlemi süreci ise temel habercilik yöntemlerinin dijital araçlarla uygulandığı bir süreç olmakla birlikte insan gücüne bağlı yürütülmektedir. Sürecin sonucunda somut veriler ve olgular eşliğinde bir analiz ortaya konulmaktadır. Analizin sonucunda șüpheli haberde ortaya konulan iddianın "yanlıș", "doğru", "karma” ya da "belirsiz" olduğu bilgisi verilmektedir (https://teyit.org/metodoloji-ve-ilkeler/).

Doğrulama platformlarının önemini ve gereğini genelde teslim etmekle birlikte bu oluşumların yalan haberle mücadelede etkinliğine ilişkin çekimser görüşler bulunmaktadır. Çekimser kalınan noktalardan biri” bu tür doğrulama hizmeti sunan organizasyonların, "güvenirlik sorunu' yaşayabileceği ve bu nedenle yeterli düzeyde etkinlik sağlayamayacağıdır. Haber doğrulama sitelerinin halk arasında ne derece yararlı ve güvenli bulunduğunu ölçmeye çalışan bir araştırmaya göre (Brandtzaeg ve Folstad, 2017) sitelerin yararlı bulunduğu, ancak güvenilirliğinin yüksek olmadığı sonucuna varılmıştır. Araştırma, doğrulama sitelerinin sahibinin kimliğinin, finansal kaynağının, organizasyon yapısı ve amacının ve doğrulama sürecini ne denli şeffaf yaptığının güvenilirlikleri konusunda belirleyici kıstaslar 
olarak bulgulamıștır. Doğrulama sitelerin güvenirlik sorununun ardındaki en önemli sebep 'politik yanlılık' ile ilgili şüphe ve kaygılardan kaynaklanmaktadır. Bunun nedeni, bu tür platformların gelişim süreci içinde partizan doğrulama sitelerinin ortaya çıkması ve özellikle siyasi kampanyalar ya da siyasi seçimlerde hedef tahtalarına rakip adayları ya da partileri oturtmaları olmuştur (Dobbs, 2012, 11). Partizan doğrulama sitelerinin yarattı̆̆ güvenirlik sorunu, tarafsız doğrulama sitelerinin önemini ve bu yöndeki ihtiyacı arttırmış ve tarafsızlık kaygısını ve iddiasını daha güçlü bir şekilde öne çeken yeni doğrulama sitelerinin ortaya çıkmasını sağlamıştır. Bu doğrultuda, geniş çapta tanınırlık sahibi olabilen ilk tarafsız doğrulama sitesi Factcheck.org. ABD'de Pensilvanya Üniversitesi bünyesindeki Annenberg Vakfı tarafından 2003 yılında kurulmuştur. Partizan doğrulama sitelerinin yarattı̆̆ durum aynı zamanda, özellikle politik veya çatışmalı konular hakkındaki haberler üzerine yoğunlaşan doğrulama sitelerinin diğerlerine göre güvenirlik ve yararlılık konusunda itibarını sağlamlaştırmaya çok daha fazla ihtiyacı olduğunu göstermiştir (Brandtzaeg ve Folstad, 2017, 66).

Diğer bir çekince konusu, herhangi bir (kasıtlı) politik yanlılık söz konusu olmasa bile, bu sitelerin yaptığı doğrulama pratiğinin geleneksel habercilikteki "objektiflik kriteri"ni (haberdeki taraflara dengeli yer verme, eşit mesafede durma) sağlamaktan uzak olduğuna dairdir. İnternet doğrulama sitelerinin çatışan iki kurumsal mantık ("geleneksel gazetecilik mantığı" ile "network mantığı") arasındaki farklılıkları uzlaştırıcı bir konuma sahip olduğunu ifade eden Wilson Lowrey'e $(2015,381)$ göre bu durum bir eksiklik ya da olumsuzluk değildir. Her kurumsallaşmanın meşruiyetini ve yetkisini bir kaynağa dayandırma ihtiyacında olduğunu belirten Lowrey, geleneksel gazetecilik mantığına göre haber kurumları meşruiyet iddialarını "objektif olmak" üzerinden temellendirmektedir. Bu mantıksal işleyiş alanın profesyonel özerkliğini sağlamakta ve aynı zamanda alandaki güçlü kurumların yararına işleyecek şekilde statükoyu güçlendirmektedir. "Bilgi teknolojileri alanı ve dijital ağlar fenomeninin içinden temellenen network mantığı" ise artık gazeteciler için farklı meşruiyet ve yetki kaynaklarını geçerli hale getirmiştir.

Network mantığında yetkinin dayandırıldığı temel, sayısız kaynaktan elde edilen büyük miktar ve kapsamdaki enformasyon, bu enformasyonun șeffaf bir șekilde kıyaslanabilir ve dönüştürebilir olmasıdır. Meşruiyetin dayandırıldığı kaynak ise enformasyona (göreceli) eşitlikçi erişebilirlik durumudur. Network mantığl, geleneksel gazetecilik mantığının -hiyerarşik olarak müdahale edilmiş hikâye anlatımı ve kasıtlı (ya da yapay olarak) kaynaklar arası denge kurulması-altını oyan bir anlayıș geliştirmiştir. Lowrey’e göre iki farklı mantık arasındaki bu çatışma nedeniyle gazeteciler meşruiyetleri yitirmemek için iş yapma pratiklerini ve yöntemlerini yeniden biçimlendirmek zorundadır. Lowrey, haber doğrulama organizasyonlarını bu yeniden biçimlendirme çabalarından biri olarak görmek gerektiğini de ifade eder. Bu oluşumlar, bu siteler geleneksel gazetecilikte geçerli olan haber toplama ve politik kaynaklara erişim gibi pratiklerle uyumlu bir işleyiștedir. Fakat geleneksel gazetecilerin benimsedikleri objektif olma rolü ile uyumlu değildirler. Doğrulama siteleri taraf tutabilirler, internetten bilgi toplayıp, birleștirebilir ve bunları okuyuculara kesin yargılarla iletebilirler. Lowrey'in çalışması kapsamında görüştüğü teyit/doğrulama platformu Politifact.com'un editörü bu durumu şöyle açıklamaktadır: "Biz doğrulama materyali için blogları, yerel haberleri, Youtube'ı 'yanlış/sahte denge' tuzağına düşmekten sakınarak tararız” (Aktaran: Lowrey, 2015, 382). 
Doğrulama platformlarının yetersiz olabileceğine dair bir diğer görüş ise, doğrulama sitelerinin insan emeğine ve dikkatine dayanan yapılar olmasıdır. Doğrulama sürecinin dikkat gerektiren ve yavaş bir süreç olması nedeniyle yalan bir haberin fark edilip, kontrolün yapılması ve ardından kamuoyuna duyurulmasına kadar geçen zaman içinde defalarca paylaşılabileceği ve süre zarfında zararın çoktan gerçekleşmiş olacağı ifade edilmektedir. Haber akışının olduğu platformlarının takibinin, doğruluk kontrolü yapılacak haberleri ya da haberlerdeki unsurları belirlemenin, bunları öncelik sırasına göre değerlendirmenin ve ardından doğrulama işlemlerini gerçekleștirmenin gerektirdiği zamanın büyüklüguü düşünüldügünde bu endişe haklı görünmektedir. Çözüm olarak ise doğrulama işlemlerini gerçekleştiren insanların işlerini kolaylaştıracak yardımcı teknolojilerin geliştirilmesi ya da yapay zekâ benzeri insanlara bağımlı olmayan doğrulama sistemlerinin geliștirilmesi önerilmektedir (Dale, 2017). Son dönemlerde Facebook'n başlattığı girişimler ile Google'ın uygulamaya koymak için üzerine çalıştığı güvenilirliği yüksek haber sitelerini öne çlkarmaya ve doğruluğu olmayan içerikler paylaşan siteleri ise geri plana atmaya dönük sistemi bu tür önlemlere örnek olarak verilebilir. Ayrıca, doğrulama noktasında Google görseller de önemli bir işlev görmektedir.

Teyit işlemlerinin yalan/sahte habere inanma eğiliminde olan kişiler üzerinde herhangi bir etkisi olamayacağına dair yaplan tartışmalar, teyit/doğrulama platformların etkinliğinin sorgulanması bağlamında ele alınmayı hak eden diğer bir konudur. İnsanların önceden sahip oldukları inanç ve düşünceleriyle çatışan gerçekleri görmezden gelme eğilimi taşıdığı belirtilerek, teyitlenmiş bilgiye karşı "inanç direnci" (belief persistence) gösterecekleri ve yalan haberin etkisini sürdürmeye devam edeceği belirtilmektedir (Brandtzaeg ve Folstad, 2017; Garrett ve diğerleri, 2013; Nyhan ve Reifler, 2010). “İnanç direnci”nin özellikle politik konularda ve çatışmalı durumlarda, diğer bir ifade ile politik taraftarlığın söz konusu olduğu konumlanmalarda daha yaygın olduğu ifade edilmektedir (Kuklinski ve diğerleri, 2000; Nyhan ve Reifler, 2010). Teyidi yapılmasına rağmen yalan haberin olumsuz etkisinin devamını açıklamak için kullanılan bir diğer kavram "inanç ekoları"dır. İnanç ekolarının iki şekilde oluşabilmesi mümkün olabilmektedir. Birincisinde yalan haberle karşılaşınca bireylerde otomatik olarak oluşan olumsuz yargıların, haberin konusu olan kişi ya da kurumlara karşı sonraki tutumlarını farkında olmadan etkilemesi. Diğerinde ise bireylerin "ateş olmayan yerden duman çıkmaz" yaklaşımıyla bilinçli bir şekilde olumsuz tavırlarını devam ettirmeleri söz konusu olmaktadır (Thorson, 2016, 464).

\section{Sonuç}

Genel olarak ekonomik ya da politik "getiri" beklentisiyle üretilen yalan/sahte haberin kamuoyunu etkileme gücünün günümüzde daha da artarak, ileri bir boyuta ulaştığı görülmektedir. Yalan haber, birçoklarınca hakikatin "sahte gerçekler" ya da "inanılmış gerçekler" karşısında değer yitirişini imlemek amacıyla post-truth olarak da adlandırılan içinde bulunduğumuz çağın en önemli belirleyicilerinden biri olarak gösterilmektedir. Manipülatif haberlerin güç kazanmasına dair sorumlu arayışında ise sosyal medya önemli bir konuma oturtulmaktadır. Sosyal medya sitelerinin ticarileşmiş ekonomi politik yapıları gereği, daha çok reklam geliri hedefleyen algoritmalar kullanması, daha çok tıklanma için yalan haber üretimini teşvik edici bir rol oynaması nedeniyle eleştirilmektedir. Kullanıcıların beğenileri ve eğilimleri doğrultusunda içerikleri gözeten algoritmalarının yol açtığı yankı odaları ve filtre 
baloncukları da, kişilerin kendi eğilimleriyle uyuşan manipülatif bilgilere çok daha fazla maruz bıraktığı için benzer eleştirilerin konusu olmaktadır.

Sosyal medyanın sorumlu tutulmasının bir diğer nedeni ise herhangi bir gazetecilik eğitimi almayan ve mesleğin etik ya da yasal sorumluluklarını taşımayan sıradan internet kullanıcılarını da potansiyel haber üreticisi haline dönüştürmüş olmasıdır. Bu doğrultuda sosyal medya üzerinden yürütülen yurttaş gazeteciliği ve geleneksel gazetecilerin sosyal medyayı haber kaynağı olarak kullanma pratiklerinin ortaya çıkması tartışmalı alanların da oluşmasına neden olmuştur. Geleneksel gazeteciliğin haber üretim sürecindeki kontrol ve denetim mekanizmalarına benzer süzgeçlerin sosyal medyada olmayışı, tartışmaların odaklandığı konuların başında gelmektedir.

Yalan/sahte haberle mücadelenin nasıl yapılacağına yönelik tartışmalarda hem internet dışından hem de internetin kendi içinden müdahaleyi içeren yöntemlerinin söz konusu edildiği görülmektedir. Yalan haber artışının post-truth bir dönemin oluşmasında etkisi büyük olmakla birlikte, bu etkiyi güçlendiren en önemli nedenin, kişilerin kendi görüş ve inançlarına sıkı sıkı sarılmak adına yalan ya da yanlış bilgilere ya da yorumlara inanmaları, yorumu hakikat sanmaları ya da kendilerini farklı görüşlere kapatmaları olduğu belirtilmektedir. Haber tüketicilerine sosyal medyada karşılaştıkları haberlere karşı eleştirel yaklaşma alışkanlığı kazandıracak ve onlara bilişsel hazırlık sağlayacak eleştirel medya okuryazarlığı bu noktada önemli bir mücadele yöntemi olarak belirmektedir. Ancak, yalan haberin çok hızlı yayılabildiği düşünüldügünde daha pratik ve hızlı bir müdahale olanağı sunan internet haber teyit/doğrulama platformları öne çıkmaktadır. İnternet teknolojisinin sunduğu hız, geniş bir alana yayılım ve çok sayıda kişiye erişim olanağı gibi avantajlar bu oluşumları güçlü kılan özellikler arasındadır. Diğer yandan, doğrulama sitelerinin yalan haberle mücadelede ne denli etkin bir rol oynayabileceğine dair şüphe ve endişeler, bu oluşumların sorgulanmasına da yol açmaktadır.

Doğrulama platformlarının yurtdışındaki örneklerinin sorgulandığı konu başlıklarının ise "politik yanlılık", "doğrulama ișleminin objektifliği", "güvenirlik" ve "önyargıları aşmanın zorluğu" gibi bu tür organizasyonların sinırlılıkları tanımlamaya dönük olduğu görülmektedir. Sosyal medya üzerinden akan içeriğin miktarının büyüklüğü ve baş döndürücü hızı ile doğrulama işlemlerinin zaman ve yoğun dikkat gerektiren meşakkatli bir süreç olduğu dikkate alındığında, insan emeği ve dikkati ile çalışan doğrulama organizasyonlarının ne denli yeterli olacağı sorusu anlam kazanmaktadır. Bu noktada, doğrulama işlemlerini kolaylaştıracak yardımcı teknolojilerin geliştirilmesi, sorunun çözümüne katkı sağlayacak bir yöntem olarak önerilmektedir. Aynı zamanda yalan/sahte haberin yaygınlaşma zeminine en çok kavuştuğu sosyal medya yapılarıyla teyit/doğrulama platformları arasında oluşabilecek işbirlirliklerinin önemi de dikkat çekilmektedir. Yalan haberlere inanma eğilimde olan ve haberlere önyargıyla yaklaşacak okurlar için ise, internet doğrulama sitelerinin sağlayacağı yarar kısıtlı olacaktır. Ancak, haberler karşısında şüpheye düşen okurlar ya da gerçekten ne olup bittiğinin bilgisinin peşine düşenler için haber doğrulama siteleri gerekli ve önemli teyit mekanizmalarıdır. Başvurulabilecek teyit mekanizmalarının varlığı kadar bu mekanizmalarının "güvenilirlik" sorununu aşmış yapılanmalar olması da onların etkinliği açısından önem taşımaktadır. Bu doğrultuda, sahiplik, gelir, doğrulama sürecinde kullanılan kriterler ve yayın ilkeleri konularında şeffaf politikalar izlenmesi, haber doğrulama sitelerinin güvenirliğini artıracak unsurlar olarak ortaya çıkmaktadır. 
Değinilen tartışmaların ışığında, internet haber doğrulama sitelerinin yalan/sahte haberle mücadelede tek başına yeterli olabilecek bir etkinlikte olduğunu söylemek güç gözükmektedir. Yalan haberle mücadelede önemli bir işleve sahip olmakla birlikte, internet haber doğrulama sitelerine sorunu tamamen çözebilecek bir "kurtarıcı" dan ziyade mücadele sürecini güçlendirecek bir "uyarıcı" olarak yaklaşmak daha anlamlı görünmektedir. Ancak, diğer yandan bu tür platformların henüz gelişim sürecinde olduğu ve zamanla etkinliklerinin daha da artabileceği de göz önünde tutulmalıdır.

\section{Kaynakça}

Alankuş, S. (2008). Yeni Habercilik Arayışları: Hak Odaklı Habercilik, Yurttaş Gazeteciliği, Barıș gazeteciliği. Gazeteciliğe Başlarken Okurdan Haber Odasına, İstanbul: IPS Vakfı Yayınları, 112-123.

Allcott, Hunt \& Gentskow, M. (2017). Social Media and Fake News in the 2016 Election. Journal of Economic Perspectives, 31(2), 211-236.

Başaran, F. (2010). Yeni İletişim Teknolojileri, Alternatif iletişim Olanakları, Mülkiye. $34: 267,255-270$.

Bilim Kazanı (t.y). https://bilimkazani.org/. Erişim: 20.4.2018.

Binark, M. (2010). Nefret Söyleminin Yeni Medya Ortamında Dolaşıma Girmesi ve Türetilmesi, (Yayına hazırlayan) Tuğrul Çomu, Yeni Medyada Nefret Söylemi, İstanbul: Kalkedon, 11-53.

Binark, M. ve Gencel-Bek, M. (2010). Eleștirel Medya Okuryazarlığı: Kuramsal Yaklaşımlar ve Uygulamalar, İstanbul: Kalkedon Yayınları.

Brandtzaeg, P. \& Folstad, A. (2017). Trust and Distrust in Online Fact-Checking Services, Communication of the ACM, 65-71.

Burkhardt, J.M. (2017). Combating Fake News in the Digital Age, Library Technology Reports, 53(8). Erişim: 2.3.2018.

Cerf, V.G. (2017). Information and Misinformation on the Internet, Communication of the ACM, 60(1), 9.

Çetin, Ö.(2015). Yeni Medyanın Tahakküm ve Özgürleşim Potansiyeli Bağlamında Hactivizm, (Editör) Filiz Aydoğan. İletişim Çalışmaları, İstanbul: Derin Yayınları, 63-81.

Dale, R. (2017). NLP in a Post-truth World, Natural Language Engineering, (23) 2, 319-324. https://www.cambridge.org/core/journals/natural-languageengineering/article/nlp-in-a-posttruth-world/30F3F9949BFF6E5644A63A80 874109A4 Erişim: 15.4.2018.

Devran, Y. ve Özcan, Ö.F. (2017). Habercilikte Hegemonya Mücadelesi: Yurttaş Gazeteciliği Fırsat mı Tehdit mi? Global Media Journal TR Edition, 7(14), 150173.

Dobbs, M. (2012). The rise of Political Fact Checking: How Reagan Inspried a Journalistic Movement: A Reporter's Eye View", The New America Foundation. https://www.issuelab.org/resources/15318/15318.pdf, Erişim: 5.7.2018.

Doğrula org.(t.y.). (https://dogrula.org/ Erişim: 20.4.2018.

Doğruluk payı (t.y.). http://www.dogrulukpayi.com/ Erişim: 20.1.2018. 
Edson C.T. Jr., Zheng, W.L. \& Richard, L. (2018). Defining 'Fake

News'. Digital Journalism, 6:2, 137-153.

Ettema, J.S. (1987). Journalism in the 'Post Factual Age. Critical Studies in Mass Communication, 4 (1), 82-86.

Flaxman, S., Goel, S. \& RAO, J.M. (2016). Filter Bubbles, Echo Chambers, and Online News Consumption, Public Opinion Quarterly, Vol. 80, 298-320.

Foça, A. M. (2016). Avrupa'da Fact-Checking: Doğrulama Demokrasinin Yeni Bekçisi mi?. 08.12.2016, https://teyit.org/avrupada-fact-checking-dogrulamademokrasinin-yeni-bekcisi-mi/. Erişim: 9.11. 2018.

Garrett, R. K., Nisbet, C. E., \& Lynch, K.E. (2013). Undermining the Corrective Effects of Media-based Political Fact Checking? The Role of Contextual Cues and Naive Theory, Journal of Communication, 63(4), 617-637.

Gillmor, D. (2004). We the Media: Grassroots Journalism by the People, the US: O'Reilly Media, http://library.uniteddiversity.coop/Media_and_Free_Culture/We_the_ Media.pdf, Erişim: 3.11.2018.

Gottfried, J. \& Shearer, E. (2016). News Use Accross Social Media Platforms, Pew Research Center, http://www.journalism.org/2016/05/26/news-use-acrosssocial-media-platforms-2016/ Erişim: 24.2.2018.

Graves, L. \& Cherubini, F. (2016). The Rise of Fact Checkig Sites in Europe, Reuters Institute, University of Oxford, https://reutersinstitute.politics.ox.ac.uk/ourresearch/rise-fact-checking-sites-europe, Erişim: 6.7.2018.

Himma-Kadakas, M. (2017). Alternative Facts and Fake News Entering Journalistic Content Production Cycle, Cosmopolitan Civil Societies: An Interdisciplinary Journal, 9(2), 25-41.

Himma-Kadakas, M. \& Palmiste, G. (2018). Expectations and the Actual Performance of Skills in Online Journalism, Journal of Baltic Studies, 1-17. https://www.tandfonline.com/doi/ pdf/10.1080/01629778.2018.1479718?needAccess=true Erişim: 6.12.2018.

Haigh, M., Haigh, T. \& Kozak, N.I. (2017). Stopping Fake News, Journalism Studies, https://doi.org/10.1080/1461670X.2017.1316681, Erişim: 23.6.2018.

İrvan, S. (2017). Yurttaş Gazeteciliği Nedir? Ne Değildir? Yeni Medya ve Gazetecilik. https://suleymanirvan.blogspot.com/2017/08/yurttas-gazeteciligi-nedirne-degildir.html Erişim: 20.4.2018.

Işıklar, G. (2017). Yeni Medya ve İnternet: Dolayımlı Sosyal Yaşam, Suat Gezgin Ali E. İralı (Ed.), Yeni Medya Analizleri içinde, İstanbul: Eğitim Kitapevi Yayınları, 99-118.

Kavaklı, N. (2018). Hate Speech towards Syrian Refugees in Turkish Online Reader Comments, C. Akrivopoulou (Ed.) Global Perspectives on Human Migration, Asylum, and Security içinde, IGI Global, 127-142.

Korkmaz, A. (2014). Etik Bağlamda Haber Fotoğrafçılığının Manipülasyon ve Propaganda Aracı Olarak Kullanılmasının Değerlendirilmesi, Gümüşhane Üniversitesi İletişim Fakültesi Elektronik Dergisi, 2 (4), 26-52. 
Kuklinski, J.H., Quirk, J.J., Schweider, D. \& Rich, R.F. (2000). Misinformation and the Currency of Democratic Citizenship. Journal of Politics, 62(3), 790-816.

Lowrey, W. (2015).The Emergence and Development of News Fact-checking Sites. Journalism Studies, 13(8), 376-394.

Jenkins, H. (2006). Convergence Culture Where Old and New Media Collide, New York: New York University Press.

Malumatfuruș. (2018). Hakkında. http://www.malumatfurus.org/hakkinda/. Erişim: 3.11.2018.

Martin N. (2017). Journalism, the Pressures of Verification and Notions of Posttruth in Civil Society, Cosmopolitian Civil Socities: An Interdisciplinary Journal, p.41-56.

Nip, J. Y.M. (2006). Exploring the Second Phase of Public Journalism. Journalism Studies, 7(2), 212-236.

Nyhan, B., \& Reifler, J. (2010). When Corrections Fail: The Persistence of Political Misperceptions, Political Behavior, 32, 302-330.

Oxford Dictionaries (t.y.). https://en.oxforddictionaries.com/definition/post-truth Erişim:6.5.2018

Pak, C. (2017). News Companies Link Sharing on Twitter as Informative Advertising and Content Signaling, Proceeding of the 2017 CHI Conference Extended Abstracts on Human Factors in Computing Systems, 312-315.

Perez, S. (2018). Facebook Expands Fact-checking Program, Adopts New Technology for Fighting Fake News, Techcrunch.com. https://techcrunch. com/2018/06/21/facebook-expands-fact-checking-program-adopts-newtechnology-for-fighting-fake-news/, Erişim: 8.11.2018.

Rubin, V.L., Conroy, N.J. \& Chen, Y. (2015). Towards News Verification: Deception Detection Methods for News Discourse, Presentation, HICSS2015, http:// works.bepress.com/victoriarubin/6/. Erișim: 10.5.2018.

Saka, E. (2015). Sosyal Medya Üzerinden Haber Doğrulama Süreçleri: Gezi Parkı Direnişi Olaylarına Bir Bakış, (Editörler) Savaş Çoban ve Yasemin İnceoğlu. Internet ve Sokak, İstanbul: Ayrıntı Yayınları, 257-278.

Silverman, C. (2016). This Analysis Shows How Fake Election Stories Outperformed Real News on Facebook, Buzzfeed News, November 16. https://www. buzzfeed.com/craigsilverman/viral-fake-election-news-outperformed-realnews-on-facebook?utm_term=.co44JwBXo\#.msldRM0Q1 Erişim: 22.4. 2018.

Taşkıran, İ. ve Kırık, A.M. (2016). Gazetecilerin Sosyal Medyayı Haber Kaynağı Olarak Kullanımı: Medya Profesyonellerinin Bakış Açılarını Tespit Etmeye Yönelik bir Araştırma, Intermedia International e-Journal, 3(1), 213-241.

Teyit org. (t.y.)., https://teyit.org/. Erişim: 12.3.2018.

Thorson, E. (2016). Belief Echoes: The Persistent Effects of Corrected Misinformation. Political Communication, 33:3, 460-480.

Tokgöz, O. (2015). Temel Gazetecilik, Ankara: İmge Kitabevi. 
Tunç, A. (2010). Medya ve Bilgi Kirliliği, içinde Tarihi Miras ve Beklentiler Arasındaki Türkiye, Ankara: Konrad Adenauer Shiftung, 245-250.

Uzun, R. (2006). Gazetecilikte Yeni Bir Yönelim: Yurttaş Gazeteciliği. Selçuk Üniversitesi Sosyal Bilimler Enstitüsü Dergisi, 16, 633-656.

Yalansavar (t.y.). https://yalansavar.org/. Erişim: 12.3.2018.

Yegen, C. (2018). Doğru Haber Alma Hakkı ve Sosyal Medya Dezenformasyonunu Doğruluk Payı ve Yalansavar ile Tartışmak, Erciyes İletişim Dergisi, 5 (4): 101-121. 